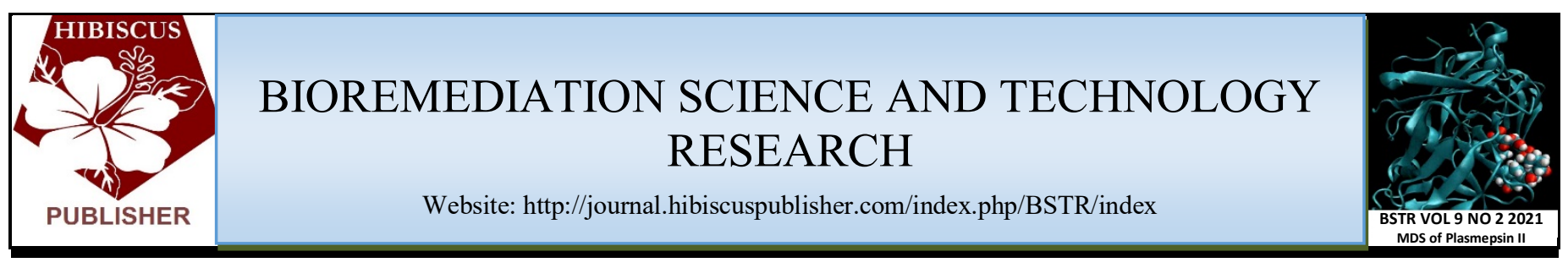

\title{
Isolation and Characterization of Biosurfactant-producing Alcaligenes sp. YLA11 and its Diesel Degradation Potentials
}

\author{
Abdulrahman Abdulhamid Arabo ${ }^{1}$, Raji Arabi Bamanga ${ }^{2}$, Mujiburrahman Fadilu ${ }^{3}$, Musa Abubakar ${ }^{4}$, Fatima \\ Abdullahi Shehu ${ }^{4}$, Hafeez Muhammad Yakasai ${ }^{1}$ and Nasiru Abdullahi ${ }^{1 *}$ \\ ${ }^{1}$ Department of Biochemistry, Bayero University, PMB 3011, Gwarzo Road Kano, Kano, Nigeria. \\ ${ }^{2}$ Department of Biotechnology, Modibbo Adama University Yola, Nigeria. \\ ${ }^{3}$ Department of Biochemistry and Forensic Science, Nigeria Police Academy, Wudil, Kano State, Nigeria. \\ ${ }^{4}$ Department of Biological Sciences, Al-Qalam University Katsina, Katsina State, Nigeria. \\ *Corresponding author: \\ Nasiru Abdullahi, \\ Department of Biochemistry, \\ Bayero University, \\ PMB 3011, \\ Gwarzo Road Kano, \\ Kano, \\ Nigeria. \\ Email: nabdullahi.bch@buk.edu.ng
}

\section{HISTORY}

Received: $23^{\text {rd }}$ Oct 2021

Received in revised form: $24^{\text {th }}$ Nov 2021

Accepted: $16^{\text {th }}$ Dec 2021

\begin{tabular}{l}
\hline KEYWORDS \\
Diesel oil \\
Biosurfactant \\
Alkanes \\
Alcaligenes sp. \\
Biodegradation
\end{tabular}

\begin{abstract}
This study aimed to isolate and identify biosurfactant producing and diesel alkanes degrading bacteria. For this reason, bacteria isolated from the diesel contaminated site were screened for their potential to produce biosurfactants and degrade diesel alkanes. Primary selection of diesel degraders was carried out by using conventional enrichment culture technique where 12 bacterial strains were isolated based on their ability to grow on minimal media supplemented with diesel as sole carbon source, which was followed by qualitative screening methods for potential biosurfactant production. Isolate B11 was the only candidate that shows positive signs for drop collapse, foaming, haemolytic test, oil displacement of more than $22 \pm 0.05 \mathrm{~mm}$, and emulsification $\left(E_{24}\right)$ of $14 \pm 0.30 \%$. The effect of various culture parameters (incubation time, diesel concentration, nitrogen source, $\mathrm{pH}$ and temperature) on biodegradation of diesel was evaluated. The optimum incubation time was confirmed to be 120 days for isolates B11, the optimum $\mathrm{PH}$ was confirmed as 8.0 for the isolate, Similarly, the optimum temperature was confirmed as $35^{\circ} \mathrm{C}$. In addition, diesel oil was used as the sole carbon source for the isolates. The favourable diesel concentration was $12.5 \%(\mathrm{v} / \mathrm{v})$ for the isolate. The isolate has shown degradative ability towards tridecane $(\mathrm{C} 13)$, dodecane, 2, 6, 10-trimethyl- $(\mathrm{C} 15)$, tetradecane (C14), 2,6,10-trimethyltridecane (C16), pentadecane (C15). It degraded between $0.27 \%-9.65 \%$ individual diesel oil alkanes. The strain has exhibited the potential of degrading diesel oil nalkanes and was identified as Alcaligenes species strain B11 (MZ027604) using the 16S rRNA sequencing.
\end{abstract}

\section{INTRODUCTION}

Petroleum hydrocarbons are a major environmental contaminant that harms the surrounding ecosystem [1]. Petroleum compounds are a common environmental pollutant that can have a negative impact on human and ecological health [2]. Because of the toxicity and carcinogenicity of petroleum products, the accidental release of hydrocarbons into soils due to transportation, spillage, and storage tanks is a major environmental concern [3]. Soil pollution caused by petroleum hydrocarbon contamination is a serious global issue. Given the amount of oil used and transported around the world, the extent of hydrocarbon contamination in the environment is unsurprising [4]. The bioremediation process has been found to be an effective method for hydrocarbon remediation [5]. Biodegradation of hydrocarbon-contaminated soils, which takes advantage of microorganisms' ability to degrade organic contaminants, has been established as an efficient, cost-effective, and environmentally friendly method [6]. The purpose of this research is to isolate and identify biosurfactant producing bacteria as well as their diesel oil degradation potential.

\section{MATERALS AND METHOD}

\section{Sample Collection}

Samples were obtained from two auto-mobile workshops in Yola Adamawa State, Nigeria. The depth for the soil collection was 0 
to $5 \mathrm{~cm}$ beneath the soil surface. Collected samples were kept at room temperature $\left(25 \pm 2^{\circ} \mathrm{C}\right)$ prior to analysis.

\section{Isolation of Bacteria}

The isolation was carried out according to [7] with slight modification. A bacterial strain that synthesizes biosurfactant was obtained from the soil samples. One gramme of the sample was incorporated with the mineral medium containing diesel $(2 \%)$. The diesel serves as the only source of carbon in the medium, and the mixtures were incubated at $35^{\circ} \mathrm{C}$ for 5 days in a shaker kept at $150 \mathrm{rpm}$. Cultures $(5 \mathrm{~mL})$ were subsequently used from the original flasks to inoculate the other flasks and were maintained at the same conditions. This procedure was repeated thrice and each time the same number of cultures were taken from the previous flasks, with subsequent replacement of a new flask. Cultures from the previous flasks were plated on a mineral salt medium (MSM) using serial dilution technique.

Morphologically distinct strains were identified from the agar plates and cultured again on MSM to get pure cultures. Pure bacteria cultures were prepared in slant vials for subsequent use.

\section{Biosurfactant Assay}

Strains were grown in MSM at $37^{\circ} \mathrm{C}$ with shaking at $120 \mathrm{rpm}$ for 18-24 hrs. Following the incubation, the bacteria strains were subjected to biosurfactant assay. This assay includes the emulsification test, oil displacement, drop collapse test and haemolytic test. The tests were performed three times and distilled water was used as control [3].

\section{Drop Collapse Assay}

Mineral oil $(3 \mu \mathrm{L})$ was applied onto a microtiter plate for equilibration at $37^{\circ} \mathrm{C}$ for $1 \mathrm{hr}$. Five microliters of the supernatant were applied onto the centre of the wells, just above mineral oil. The shape of the oil drop was assessed after a minute. A positive result for biosurfactant production gives a flattened shape, while the unflatten shape is considered a negative test for biosurfactant production.

\section{Displacement Test}

Diesel $(20 \mu \mathrm{L})$ was put into a petri dish containing $35 \mathrm{~mL}$ of distilled water. Ten microliters of Suspensions (Pellet and supernatant) were gently added to the centre of the film. Thirty seconds later the width of the hollow zone was determined.

\section{Haemolysis Test}

Each bacterial isolate was flecked on a blood agar medium, followed by incubating the medium for $1-2$ days at $37^{\circ} \mathrm{C}$, then assayed for haemolysis. The plates were examined visually for clear regions; clear regions are an indication of biosurfactant production [8].

\section{Emulsification Assay}

Diesel and culture supernatant $(4 \mathrm{~mL}$ each) were thoroughly mixed with vortexed for $5 \mathrm{~min}$. The resultant mixture was kept intact for $24 \mathrm{hrs}$. Emulsion layers were measured, and emulsion activity was calculated using the formula below:

$$
\mathrm{E} 24 \%=\frac{\text { Hight of emulsification layer }(\mathrm{mm})}{\text { Total hight of the liquid column }(\mathrm{mm})} \times 100 \%
$$

Cultural Conditions for Enhanced Biodegradation Potentials of Diesel

The optimization was carried out as reported by [9]. Effect of incubation time, carbon source, nitrogen source, $\mathrm{pH}$ and temperature (cultural conditions) were examined. Standardization of the inoculum was done with Mac- Farlane's standard for optimization.

\section{Effect of Incubation Time}

The time of incubation was varied for days to determine the optimum time and maximum biosurfactant production for the chosen strain. The strain was inoculated and cultured, while the absorbance was taken after a day. The absorbance indicates the growth of the bacteria.

\section{Effect of pH}

The $\mathrm{pH}$ and carbon source were varied while the strain was allowed to grow on MSM with $1 \%$ diesel. Following the variation in $\mathrm{pH}$, the medium was sterilized at $121^{\circ} \mathrm{C}$ for $15 \mathrm{~min}$. The strains were then inoculated and incubated at $37^{\circ} \mathrm{C}$ for 5 days in a shaker at $150 \mathrm{rpm}$.

\section{Effect of Temperature}

For temperature optimization, various temperature values that range from $25^{\circ} \mathrm{C}$ to $45^{\circ} \mathrm{C}$ were used. The $\mathrm{pH}$ of the medium was adjusted to 8.0, while the strain was cultured on MSM with diesel $(1 \%)$ as the carbon source. The medium was maintained at various temperatures for five days in a shaker (150 rpm).

\section{Variation in Carbon Source}

The source of carbon for the strain was also optimized source concentration was optimized, by choosing five concentrations $(2.5,5,7.5,10,12.5 \% \mathrm{v} / \mathrm{v}$ diesel $)$. The $\mathrm{pH}$ was kept at 8.0, and the strain was grown on MSM. The medium was maintained at $37^{\circ} \mathrm{C}$ for five days in a shaker (150 rpm).

\section{Variation in Nitrogen Source}

Two nitrogen sources selected were ammonium nitrate $\left(\mathrm{NH}_{4} \mathrm{NO}_{3}\right)$ and urea. Preparation of MSM was accomplished with $1 \%$ diesel as a carbon source with one gramme per litre of each nitrogen source. The $\mathrm{pH}$ was maintained at 8.0 , while the temperature was $35^{\circ}$ The culture was kept for five days in a shaker (150 rpm).

\section{Molecular Identification \\ 16S-rRNA amplification and sequencing}

The most efficient isolate (B11) was identified using molecular identification. The standard protocol was for DNA extraction. Segment of the 16S rDNA from the strains was amplified using specific primers sets. Forward 5'- AACGCGAAGAACCTTAC3' and Reverse 5' - AAGGAGGTGATCCAGCCGCA- 3' (White et al., 1990). PCR conditions were optimised, and amplified copy were sequenced. The results were analysed using multiple sequence alignment, and the phylogenetic tree was obtained according to [10].

\section{Gas chromatography results of isolate B11 cultures.}

Method of [11] was adopted. The constituents of diesel were analysed by employing GC-MS technique. For evaluation in the changes of different molecules, the supernatant was used which was filtered and injected into the GC analyser. Sample injection was done in ration 20:1. Determination of the composition was checked using the peaks from the chromatogram. 


\section{RESULT}

Table 1. Screening Assay for Biosurfactant production.

\begin{tabular}{cccccc}
\hline Isolate & Foaming & $\begin{array}{c}\text { Emulsi- } \\
\text { fication } \\
(\%)\end{array}$ & $\begin{array}{c}\text { Oil Displa- } \\
\text { cement } \\
(\mathrm{mm})\end{array}$ & $\begin{array}{c}\text { Drop } \\
\text { Collapse }\end{array}$ & $\begin{array}{c}\text { Haem- } \\
\text { olytic } \\
\text { test }\end{array}$ \\
\hline B11 & + & $14 \pm 0.30$ & $22 \pm 0.05$ & + & + \\
\hline Note: + positive; - negative & & & &
\end{tabular}

Out of the 12 bacterial isolates screened, one isolate was selected as biosurfactant producers based on their ability to give the positive result to drop collapse, foaming stability, emulsification and oil displacement (Table 1).

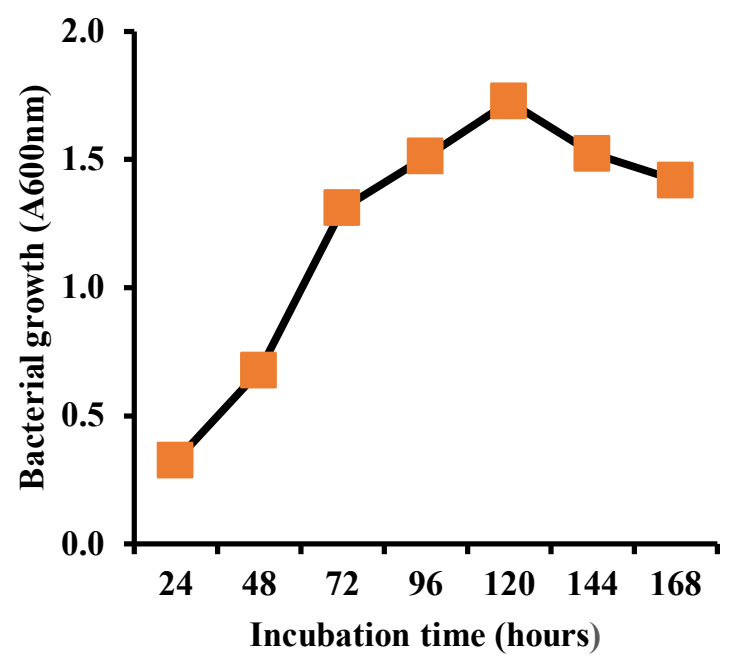

Fig. 1. The effect of incubation time on growth of isolate B11.

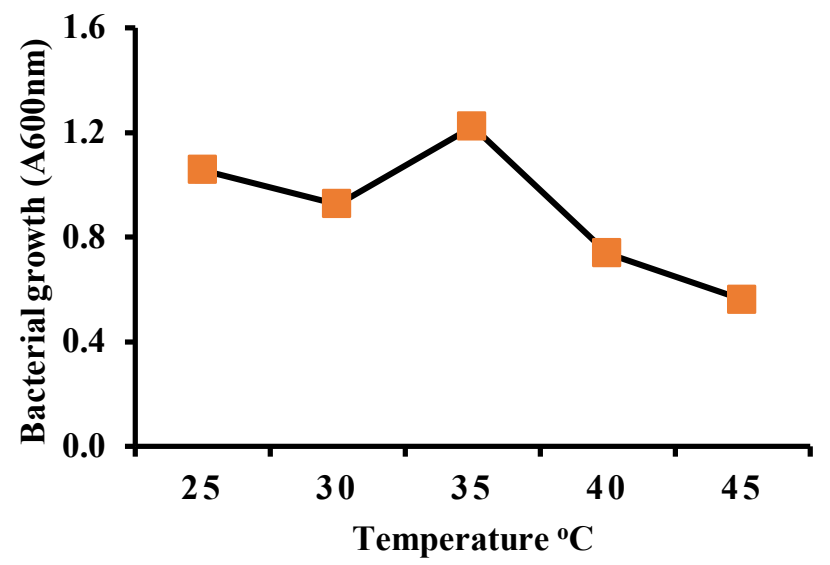

Fig. 2. The effect of temperature on growth of isolate B11.

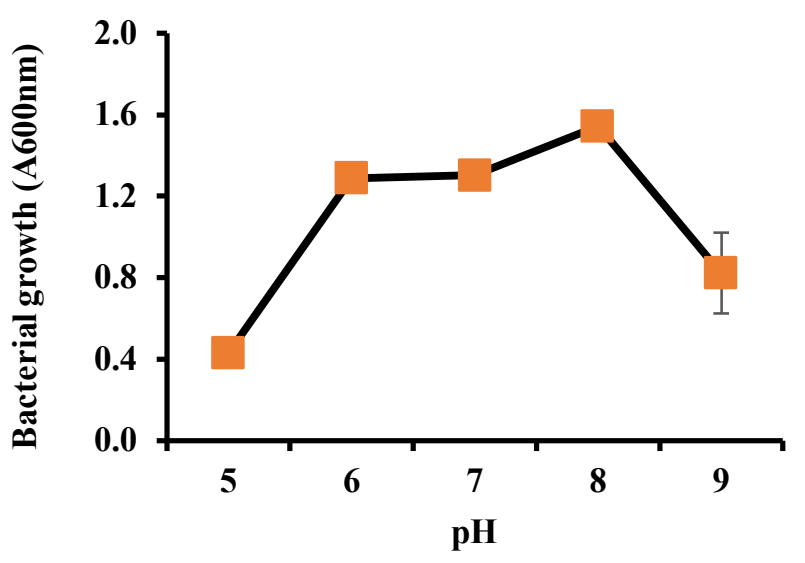

Fig. 3. Effect of $\mathrm{pH}$ on growth of isolate B11.

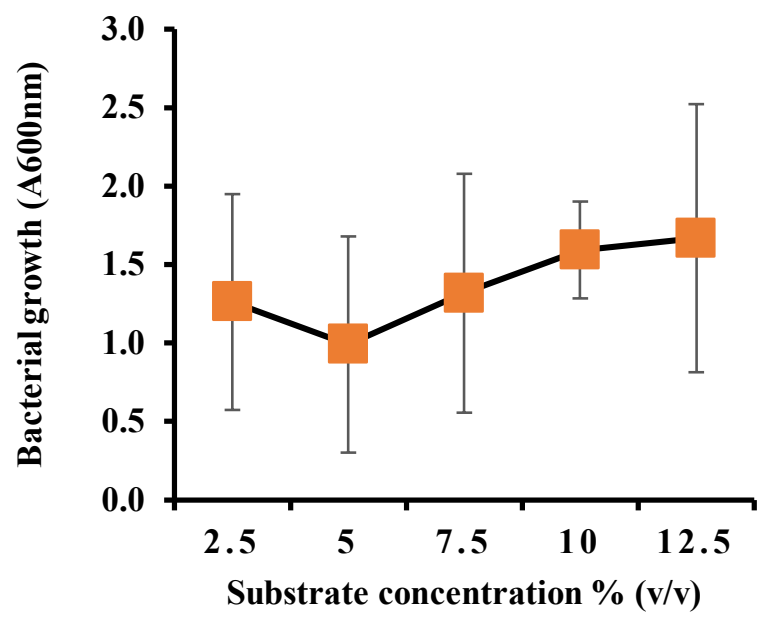

Fig. 4. Effect of diesel oil concentration on growth of isolate B11.

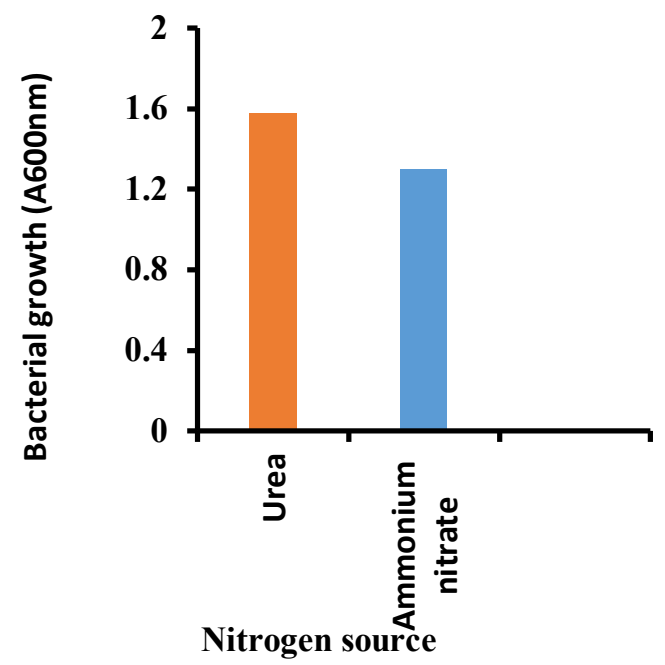

Fig. 5. Effect of nitrogen source on growth of isolate B11. 


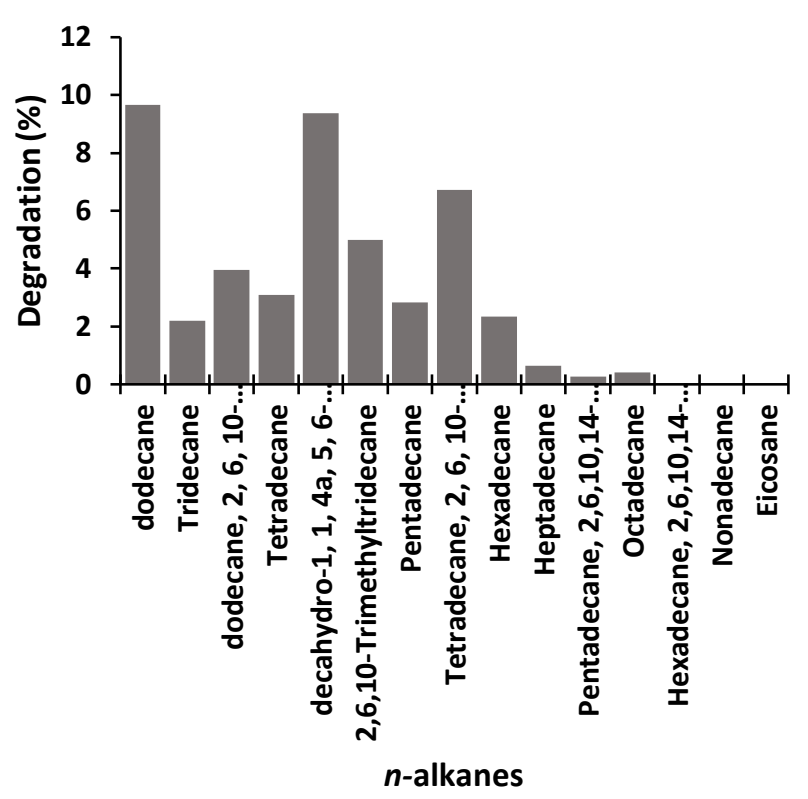

Fig. 6. Percentage degradation of some alkanes compound present in diesel oil by isolate B11.

\section{Identification of strains B11.}

Isolate $\mathrm{B} 11$ was identified using the $16 \mathrm{~S}$ rRNA sequencing. The results of 16S rRNA sequence alignment and phylogenetic tree analysis revealed that $16 \mathrm{~S}$ rRNA sequence of Isolate B11 was similar to Alcaligenes faecalis strain NBRC13111 (Fig 7). The Evolutionary distance tree is based on $16 \mathrm{~S}$ rDNA sequences with their references. Bar, nucleotide difference per sequence position is shown below.

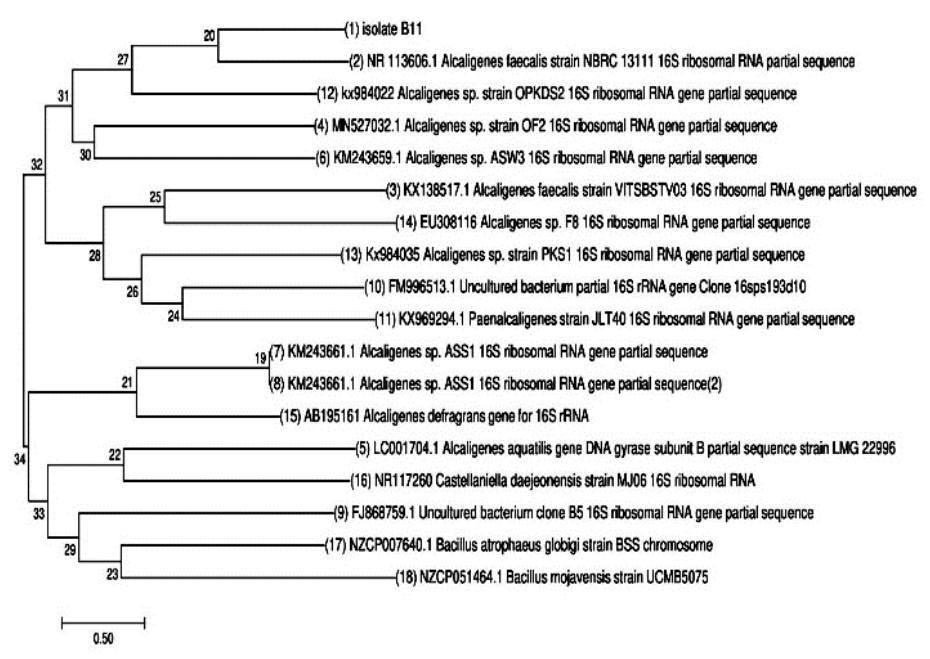

Fig. 7. Phylogenetic analysis of the $16 \mathrm{~s}$ RNA sequence of isolate B11

\section{DISCUSSION}

This study looked at the isolation and identification of biosurfactant-producing bacteria to see if they might degrade diesel n-alkanes. Twelve morphologically different bacteria strains were successfully identified from an automobile repair business in Yola in this study. Cellular morphology, which includes shape and gram responses, found that $72.6 \%$ of the isolates were cocci shaped, while the rest were Rod-shaped bacteria. In addition, the gram response revealed that $72.6 \%$ of the isolates were Gram-positive and $27.4 \%$ were Gram-negative. This result matched the findings of [12] who found that $72.7 \%$ of 11 strains isolated from the river Rido in Kaduna were Grampositive and $27.3 \%$ were Gram-negative. All of the strains could use diesel as their sole carbon source. Among the 12 strains isolated, one strain was identified and selected because of its potential to produce biosurfactants.

The effect of incubation time $(24,48,72,96,120,144$, and $168 \mathrm{~h}$ ) on test isolate development in media containing diesel oil as a carbon source was studied. For isolate B11, the optimal incubation time was determined to be $120 \mathrm{~h}$ (5 days) (Fig. 1). This finding is comparable to that of [13] who found that $120 \mathrm{~h}$ was the optimal time for isolated and biosurfactant generation. Isolate B11 optimal temperature was proven to be $35^{\circ} \mathrm{C}($ Fig. 2).

The organisms are mesophilic, meaning they work best at a moderate temperature $\left(30-35^{\circ} \mathrm{C}\right)$. Several writers have reported similar optimum conditions $[15,13,16]$. Temperature ranges are variable for different bacteria species. However, most of these bacteria grow and produce at a normal body temperature [17].

Strain B11 obtained maximum growth at $\mathrm{pH} 8$ (Fig. 3). Also, the bacteria tend to do well at $\mathrm{pH} 6$ (Fig. 3). The $\mathrm{pH}$ optimization result for the growth of isolates in the medium is consistent with that obtained by [18] in his report of biosurfactant production by Pseudomonas aeruginosa UKMP14T. According to [13] at $\mathrm{pH} 7$ Pseudomonas sp. strain F4 showed efficient diesel degradation potential. According to [20] the optimum $\mathrm{pH}$ for crude oil degradation by individual bacterial strains and a mixed bacterial consortium is 7. As a result, $\mathrm{pH}$ adjustment is critical for bacterial growth as well as the selection of an efficient bioremediation technique.

The influence of diesel as a carbon source on determining which volume bacteria isolates used the most. $12.5 \%(\mathrm{v} / \mathrm{v})$ was shown to be more favourable for isolates B11 in this study (Fig. 4). According to [21] a range of carbon sources such as Glucose, Sucrose, Maltose, and Starch (1\%) were introduced to an MSM medium containing $1 \%$ diesel oil as nutritional addition for diesel breakdown. Sucrose is one of them, and it accelerates the breakdown of diesel oil. Bacteria like to use various types of hydrocarbons as carbon sources. 
The synthesis of surface-active chemicals by microorganisms relies heavily on nitrogen. It was investigated how different test isolates grew on different nitrogen sources $\left(\mathrm{NH}_{4} \mathrm{NO}_{3}\right.$ and Urea). The results revealed that the isolate B11 grew better on mineral salt medium supplemented with Urea than on $\mathrm{NH}_{4} \mathrm{NO}_{3}$ (Fig. 5). This contradicts the findings of [18] who found that $\left(\mathrm{NH}_{4}\right)_{2} \mathrm{SO}_{4}$ was the best nitrogen source for Pseudomonas aeruginosa UKMP14T production and growth. The difference between the test isolate B11 and others could be attributable to the test isolate B11's preferential demand for a specific nitrogen source for growth and secondary metabolite production.

The degradation of n-alkanes in a diesel by isolate B11 was measured using GC-MS in this investigation. With maximal degradation percentages of $9.65 \%$ dodecane (C12). Strain B11 had limited degradation potentials (Fig. 6). Hexadecane, 2, 6, 10, 14, (C20), tetramethyl-, Nonadecane (C19), Eicosane (C20) were not degraded by Strain B11 (Fig 4.6). These findings contradict those of [22], who found that Alcaligenes species ALK-14 degraded docosane11-decyl, hexatriacontane, and eicosane by $100 \%, 60 \%$, and $48.8 \%$, respectively. Alcaligenes sp. CT10 was able to degrade diesel alkanes up to $12.5 \%$ in 36 days, according to [11] CT10 was found to degrade a number of hydrocarbons, including $\mathrm{C} 9, \mathrm{C} 10, \mathrm{C} 11$, and $\mathrm{C} 28$. Alcaligenes sp. strain 3k obtained from Ilorin, Nigeria, was also able to degrade decane, dodecane, hexadecane, eicosane, tetracosane, and hexatriacontane, according to [23].

Other investigations have identified Alcaligenes sp. as possible petroleum hydrocarbon degraders $[24,25]$. The majority of these Alcaligense are identified as part of degrading consortia. Some diesel n-alkanes did not degrade to expected levels, which could be owing to their bioavailability and solubility in bacterium cell membranes. While [26] suggested that substrate toxicity may be the cause of restricted biodegradation of long-chain alkanes.

\section{CONCLUSION}

The breakdown of diesel alkanes by bacterium species isolated from diesel contaminated soil was the subject of this study. Oil bioremediation success is contingent on the ability to control a variety of physical, chemical and biological factors in the polluted environment. At $\mathrm{pH} 8,35^{\circ} \mathrm{C}$, and a diesel concentration of $12.5 \%(\mathrm{v} / \mathrm{v})$, isolate B11 was able to degrade diesel alkanes (C12-C20) to a percentage range of $0.27 \%-9.65 \%$ in 5 days. Alcaligenes sp. was identified using the 16S rRNA isolate A3 (MZ027604) Further research is needed into the determination and characterisation of the biosurfactant produced.

\section{ACKNOWLEDGMENT}

This research work was fully supported and funded by the Petroleum Development Trust fund (PTDF). I gratefully acknowledge PTDF for its financial support.

\section{REFERENCE}

1. Ahmed F, Hasibullah M., Ferdouse J. Anwar, MN. Microbial degradation of petroleum hydrocarbon. Bangla J Microbiol, 2010; 27:10-13

2. Jiang Z, Huang Y, Xu X, Liao Y, Shou L, Liu J. Advance in the toxic effects of petroleum water accommodated fraction on marine plankton. Acta Ecol Sinica. 2010;30(1): 8-15.

3. María B-R., Panagiotis G, Petra S. K., Jonathan V-H, Nele W, Carmen M, Jaco V. Characterization and degradation potential of diesel-degrading bacterial strains for application in bioremediation, Int J Phytoremed. 2017;19(10): 955-963.

4. Koshlaf E, Esmaeil S, Arturo A-M, Mohamed Taha, Nagalakshmi H, Tanvi H.M, Paul D.M. Andrew S.B. Bioremediation potential of diesel-contaminated Libyan soil. Ecotox Environ Saf. 2016; 133:297-305.

5. Cao J, Lai Q, Yuan J. Genomic and metabolic analysis of fluoranthene degradation pathway in Celeribacter indicus P73T. Sci Report, 2015;13(5):7741-7753.

6. Dixit H, Madan L, Umema M, Mamta M, Sachin K, Ankit C, Sarika G. Screening and identification of diesel oil degrading bacterial isolates from petroleum contaminated soil of Barmer. J Pharm Chem Biol Sci, 2018;6(1):34-40

7. Wuyang S, Imran A, Jiwei L, Min D, Wenrui C, Mingyu J, Gaowa S, Xinke Y. Changsheng P, Iffat N. Isolation, identification, and characterization of diesel-oil degrading bacterial strains indigenous to Changing oil field, China J. 2019; 59:7

8. Carrillo P, Mardaraz C, Pitta-Alvarez S, Giulietti, A. Isolation and Selection of Biosurfactant-Producing Bacteria. World J Microbiol Biotech, 1996;12: 82-84.

9. Parthipan P, Preetham E, Machuca L.L, Rahman P.K, Murugan K, Rajasekar A. Biosurfactant and degradative enzymes mediated crude oil degradation by bacterium Bacillus subtillis A1. Front. Microbiol. 2017;8:193

10. Tamura K., Stecher G., Peterson D, Filipski A, Kumar S. MEGA6: Molecular evolutionary genetics analysis v 6.0. Mol Biol Evolut. 2013;30:2725-2729.

11. Liang J, Tao C, Yi H, Jianhua L. Petroleum degradation by Pseudomonas sp. ZS1 is impeded in the presence of antagonist Alcaligenes sp. CT10. AMB Expr. 2018; (8): 88.

12. Ndibe T. O, Eugene W.C, Usman J.J. Screening of BiosurfactantProducing Bacteria Isolated from River Rido, Kaduna, Nig J Appl Sci Environ Manag, 2018;22(11):18551861

13. Nwaguma I, Vivian C, Blaise C, Gideon C.O. Isolation, characterization and application of biosurfactant by Klebsiella pneumoniae strain IVN51 isolated from hydrocarbon-polluted soil in Ogoniland, Nig Biores Bioproc, 2016; 3:40.

14. Satpute S. K, Bhawsar B. D, Dhakephalkar P. K, Chopade B. A. Assessment of different screening methods for selecting biosurfactant producing marine bacteria. Ind J Mar Sci, 2008; 37(3): 243-250.

15. Patil S, Anuradha P, Aruna K. Studies on optimization of biosurfactant production by Pseudomonas aeruginosa F23 isolated from oil contaminated soil sample. Int J Curr Biotech. 2014; 2(4):20-30.

16. Mnif I, Sahnoun R, Ellouze-Chaabouni S, Ghribi D. Evaluation of B. subtilis SPB1 biosurfactants' potency for diesel-contaminated soil washing: optimization of oil desorption using Taguchi design Environ Sci Pol Res, 2014;21:851-861.

17. Chander S, Lohitnath C. R, Mukesh T, Kumar D. J, Kalaichelvan P. T. Production and characterization of biosurfactant from Bacillus subtilis MTCC441 and its evaluation to use as bioemulsifier for food bio-preservative. Adv Appl Sci Res J, 2012;3(3):1827-1831.

18. Hamzah, A, Chia-Wei P Bakar N A. Wong K. K. Biodegradation of crude oil by constructed bacterial consortia and the constituent single bacteria isolated from Malaysia. Biorem J, 2013;17(1):1-10.

19. Luo Q, Xian-Rong S, Jiang-Gou Z, Zheng-Qui F, Ying H. Isolation, identification, and biodegradation ability of diesel oil degrading Pseudomonas sp. strain C7 from bilge water. Afr J Microbiol, 2012;6:1033-1040

20. Sathishkumar M, Binupriya A. R, Baik S-H, Yun S-E Biodegradation of crude oil by individual bacterial strains and a mixed bacterial consortium isolated from hydrocarbon contaminated areas. Clean-Soil Air Water, 2008;36:92-96.

21. Sivagamasundari T, Jayakumar N. Optimization of Diesel oil degrading Bacterial strains at various culture parameters. Int J Res Develop PharmaLife Sci, 2017;6(6):2840-2844.

22. Dwivedi A, Kumar A, Bhat J. L. Production and characterization of Biosurfactant from Corynebacterium species and its effect on the growth of petroleum degrading bacteria. Microbiol. 2019; 88:8793. 
23. Adetitun D. O., Fathepure B, Hugh H, Kolawole O. M. Olayemi A. B. Degradation of Hydrocarbons and Lignin-like compounds by Alcaligenes sp. strain 3k isolated from Ilorin. Pollution, 2019; 5(2): 269-277.

24. Ijah, U, Antai S. Removal of Nigerian light crude oil in soil over a 12-month period. Int Biodeterior Biodeg, 2003; 51: 93-99.

25. Li Y.-M., Chu C.-C, Cheng Y.-T, Teng, H.-C and Cherng S. The study of a novel microstrip antenna being used for the estimation of sample material dielectric coefficient under electromagnetic wave at 2.4 GHz. Nat Sci. 2006;4:41-44.

26. Deng M.C, Li J. Liang F.R., Yi M, Xu X. M, Yuan J. P, Peng J, Wu C.F, Wang J.H. Isolation and characterization of a novel hydrocarbon-degrading bacterium Achromobacter sp. HZ01 from the crude oil-contaminated seawater at the Daya Bay, southern China Mar Poll Bull, 2014;83:79-86. 